\title{
The Administrative and Legal Status of the Subjects of Public administration that Provide Legal Support for the Circulation and Use of Weapons in Ukraine, Including Space Weapons
}

\author{
Serhiy Didenko
}

Doctor of Law, Professor, Honored Lawyer of Ukraine,

Director of the Kherson Institute of "Interregional Academy of Personnel Management"

(Kherson, Ukraine)

E-mail: sergii_didenko@ukr.net

https://orcid.org/0000-0003-3349-4046

In the paper, the author examines the administrative and legal status of subjects of public administration in the sphere of ensuring the circulation and use of weapons in Ukraine, including space weapons. Under the space weapon, the author understands not only weapons that can attack space systems in orbit, attack targets from outer space or disconnect space-borne rockets, but also those weapons developed on technology working exclusively for space and research. Such weapons have greater operational efficiency and sensitivity.

Keywords: Space weapon. administrative status, arms turnover, public administration

\section{Адміністративно-правовий статус суб’сктів публічної адміністрації які здійснюють правове забезпечення обігу \\ та застосування зброї в Україні, включаючи космічну зброю}

\section{Діденко, Сергій Володимирович}

Доктор юридичних наук, професор, Заслужений юрист України, директор Херсонського інституту «Міжрегіональної Академії управління персоналом» (Херсон, Україна)

(C) Didenko, Serhiy, 2018 
The Administrative and Legal Status of the Subjects of Public administration that Provide Legal Support for the Circulation and Use of Weapons in Ukraine, Including Space Weapons by Serhiy Didenko

У статті досліджується адміністративно-правовий статус суб'єктів публічної адміністрачії у сфері забезпечення обігу та застосування зброї в Україні, включаючи космічну зброю. Під космічною зброєю автор розуміє не тільки зброю, яка може атакувати космічні системи на орбіті, атакувати цілі на землі з космосу або відключати ракети, щьо подорожують через космос, але і ту зброю що розроблена на технологіях прачюючих виключно для космосу та його дослідження. Така зброя має більшу оперативну ефективність та чутливість.

Ключові слова: космічна зброя, адміністративно-правовий статус, обіг зброї, публічна адміністрачія

Received: June 19, 2018; accepted: August 5, 2018

Advanced Space Law, Volume 2, 2018: 12-20.

https://doi.org/10.29202/asl/2018/2/2

\section{Постановка проблеми}

Процес побудови незалежної правової держави передбачає наявність цілісної та ефективної системи органів державної влади, які покликані забезпечувати виконання завдань та функцій держави через управлінський механізм, наділений владними повноваженнями. Саме тому, все частіше поняття «публічна адміністрація» зустрічається у нормативно-правових актах України і розглядається як сукупність владних суб' єктів, що забезпечує цей управлінський механізм. Артем Зубко у статті «Адміністративно-правовий статус публічної адміністрації, яка здійснює адміністративно-правове регулювання у сфері космічної оброни України» переосмислює поняття «космічна оборона», та адміністративно-правовий статус публічної адміністрації, яка здійснює адміністративно-правове регулювання у сфері космічної оброни України [Zubko, 2018]. Мета нашого дослідження - на основі теорії адміністративного права, аналізу відповідних нормативно-правових актів, праць вчених та інших джерел з'ясувати адміністративно-правовий статус суб'єктів публічної адміністрації у сфері забезпечення обігу та застосування зброї в Україні, включаючи космічну зброю. Під космічною зброєю ми розуміємо не тільки зброю, яка може атакувати космічні системи на орбіті, атакувати цілі на землі 3 космосу або відключати ракети, що подорожують через космос, але і ту зброю що розроблена на технологіях працюючих виключно для космосу та його дослідження. Така зброя має більшу оперативну ефективність та чутливість (наприклад, дослідження [Ding et al., 2016]).

\section{Виклад основного матеріалу}

Тетяна Кравцова та Анастасія Солонар у статті «Поняття та принципи діяльності публічної адміністрації» слушно зазначають, що публічна адміністрація здійснює певний цілеспрямований вплив іiї суб'єктів на ті сфери життєдіяльності суспільства, які потребують такого впливу, з метою узгодження та задоволення як інтересів держави, так і інтересів суспільства. При цьому кожен суб〉єкт публічної адміністрації наділений відповідною компетенцією, яка, як правило, дає йому можливість вибирати у конкретних ситуаціях той чи інший варіант поведінки, варіант конкретних дій, тобто відбити зміст своєї регулятивної, сервісної або управлінської діяльності [Кравцова \& Солонар, 2010]. 
The Administrative and Legal Status of the Subjects of Public administration that Provide Legal Support for the Circulation and Use of Weapons in Ukraine, Including Space Weapons by Serhiy Didenko

Таким чином, основне завдання публічної адміністрації полягає у цілеспрямованому впливі певних владних суб' єктів на конкретну сферу суспільного життя, що потребує на основі інтересу держави і суспільства врегулювання шляхом реалізації їх законодавчо прописаної компетенції.

Публічна адміністрація — це певним чином побудована система органів державної виконавчої влади та виконавчих органів місцевого самоврядування, підприємства, установи, організації та інші суб’єкти, наділені адміністративно-управлінськими функціями, які діють з метою забезпечення як інтересів держави, так і інтересів суспільства в цілому. При цьому, їй притаманні властивості, які відрізняють ііі від інших державних утворень і які можна побачити у визначенні даного поняття. Діяльність усіх державних органів базується на певних принципах, не є виключенням і публічна адміністрація, вона також діє у відповідності до певних принципів: верховенство права, гуманізм, законність, демократизм, професійна компетентність, відповідальність тощо [Кравцова \& Солонар, 2010: 523].

Виходячи з цього, публічна адміністрація в сфері забезпечення обігу та застосування зброї є сукупністю передбачених законодавством, уповноважених органів та посадових осіб, наділених адміністративно-управлінськими функціями щодо належного забезпечення обігу та застосування зброї, діяльність яких базується на певних обов'язкових адміністративних принципах з метою задоволення публічних інтересів в межах сфери їх правового впливу.

У відповідності до Конституції України та законів України владними повноваженнями наділені державні органи, органи місцевого самоврядування, їх посадові і службові особи. А сама наявність владних повноважень визначається правовим статусом, тобто обсягом прав та обов'язків органів державної влади. Щодо органів публічної адміністрації, то вони наділені адміністративно-правовим статусом [Шиленко, 2014: 98].

Таким чином, щоб з'ясувати адміністративно-правовий статус суб'єктів публічної адміністрації, які здійснюють адміністративно-правове забезпечення обігу та застосування зброї в Україні, включаючи космічну зброю, потрібно звернутися до доктринальних підходів категоріальнго апарату, а потім окреслити систему суб'єктів, які безпосередньо наділені владними повноваженнями в цій сфері.

Загалом, поняття «статус» є одним із фундаментальних у юридичній науці, оскільки дає можливість визначити місце суб'єкта права в системі суспільних відносин, його права і обов'язки стосовно інших суб'єктів. Зокрема, словник української мови трактує поняття ста́тус «як становище, стан; певний стан чого-небудь». Етимологічно «статус» походить з латини й означає правове становище осіб або організацій, установ тощо; становище індивіда або групи осіб щодо інших індивідів або груп у соціальній системі; встановлене нормами права положення його суб'єктів, сукупність їх прав i обов'язків [Словник, 1974: 565]. Розглядаючи різні визначення поняття правового статусу, можна узагальнити, що правовий статус — це регламентоване нормами права існуюче становище суб〉єкта в певній системі, яке залежить від структури, прав, завдань і відповідальності. При цьому, правовий статус суб〉єктів права складається з об〉єктивних, фактично існуючих елементів, виявивши та проаналізувавши які, в цілому можна пізнати явище комплексно. Усвідомивши правовий статус як цілісну систему, серед структурних елементів якої можна виділити головні, можна з'ясувати характер іiї взаємозв'язків з середовищем функціонування. Застосовуючи системний метод дослідження, можна визначити поняття «правовий статус» як комплексне юридичне явище, 
що визначає статус (становище) суб〉єкта у відповідній системі, відокремити його статистичні й допоміжні елементи [Ринажевський, 2010: 18]. Відповідно, поняття «правовий статус» охоплює своїм змістом місце в системі державних органів конкретного суб'єкта, який безпосередньо здійснює регулюючий вплив в конкретній сфері суспільного життя на основі своєї компетенції. Таким чином є можливість стверджувати, що адміністративно-правовий статус це конкретне поняття, яке охоплює своїм змістом певні складові елементи за допомогою яких з'являється можливість дослідити місце певного суб'єкта в усій системі регулюючого впливу з боку держави на певні суспільні відносини.

Адміністративно-правовий статус органів публічної адміністрації включає в себе обсяг владних повноважень, а саме компетенцію, закріплену у компетенційних (або «статутних») нормативно-правових актах, що доповнюється важливими елементами завданнями, функціями, характером взаємозв'язків з іншими органами (як «по вертикалі», так і «по горизонталі»), місцем в ієрархічній структурі органів виконавчої влади, порядком вирішення установчих і кадрових питань [Шиленко, 2014: 99]. Таким чином, щоб з'ясувати сутність адміністративно-правового статусу суб'єктів публічної адміністрації в сфері забезпечення обігу та застосування зброї необхідно сформулювати перелік державний органів, наділених владною компетенцією, визначити їх місце та роль в регулюючому впливі, окреслити коло їх повноважень в цій сфері.

Статус, основні завдання, організація та принципи діяльності, права та обов>язки, відповідність в сфері обігу та застосування зброї повинні бути передбачені у спеціально створеному законі, якого, в цій сфері наразі немає. Це дещо ускладнює процес визначення статусу публічної адміністрації в цій сфері, адже необхідно проаналізувати низку відомчих нормативно-правових актів.

За обсягом компетенції у сфері нормотворчої діяльності провідну роль виконує Кабінет Міністрів України. Але деякі питання щодо обігу зброї регулюються іншими суб'єктами влади, наприклад, Верховною Радою України та президентом України. Певні нормотворчі повноваження мають і окремі органи виконавчої влади, серед яких провідне місце посідає Міністерство внутрішніх справ України. Не мало важливе значення мають його структурні підрозділи, оскільки саме на них покладено в більшій мірі обов'язків по забезпеченню даної сфери.

На разі ще діє Інструкція про порядок виготовлення, придбання, зберігання, обліку, перевезення та використання вогнепальної, пневматичної і холодної зброї, пристроїв вітчизняного виробництва для відстрілу патронів, споряджених гумовими чи аналогічними за своїми властивостями метальними снарядами несмертельної дії, та зазначених патронів, а також боєприпасів до зброї та вибухових матеріалів, затверджена Наказом МВС України від 21 серп. 1998 р. № 622. Центральне і основоположне місце в цій Інструкції займає МВС, та його структурні підрозділи.

Основними завданнями органів внутрішніх справ, в цій сфері, є запобігання порушенням порядку виготовлення, придбання, зберігання, обліку, охорони, перевезення та використання вогнепальної зброї, пневматичної зброї калібру понад 4,5 мм та швидкістю польоту кулі понад 100 метрів за секунду (пневматична зброя) і холодної зброї (арбалети, луки з зусиллям натягу тятиви більше ніж 20 кг, мисливські ножі тощо (холодна зброя), пристроїв вітчизняного виробництва для відстрілу патронів, споряджених гумовими чи аналогічними за своїми властивостями метальними снарядами несмертельної дії, та патрони до них, основних частин зброї бойових припасів до зброї і оголошеної 
зброї, вибухових матеріалів і речовин, попередження випадків їх втрати, крадіжок, використання не за призначенням та з протиправною метою [Інструкція, 1998].

Відповідальними підрозділами, за вище згаданою Інструкцією є: ДГБ, УВСТ, ДКР, ДДСБЕЗ, ГУБОЗ, ГУКП, ГСУ, ДНДЕКЦ, ДРЗ, УМВС України на транспорті,УДАІ, ДДСО, Головний штаб МВС. Ось, зокрема як приклад, ГСУ, Відділ дізнання МВС України відповідальний за: своєчасне і якісне розслідування справ, пов'язаних з крадіжками зброї, боєприпасів та вибухових матеріалів, а також незаконним їх володінням, зберіганням і носінням; ДРЗ МВС України за: виконання роботи щодо обліку, зберігання, знищення чи реалізації вилученої, добровільно зданої та знайденої зброї; Головний штаб MBC України за: забезпечення приймання, зберігання та охорони черговими частинами, міськрайлінорганами внутрішніх справ вилученої, добровільно зданої та знайденої зброї; ДДСО МВС України за: забезпечення засобами охоронної сигналізації обьєктів дозвільної системи, укомплектування підрозділів воєнізованої охорони особовим складом, спроможним за своїми діловими якостями та станом здоров〉я забезпечити надійну охорону цих об〉єктів, тощо [Інструкція, 1998].

При цьому, спостерігається переважаюча дія цього акта суб'єкта публічного адміністрування, оскільки він був прийнятий для деталізації положень Закону України «Про міліцію», який на даний момент втратив чинність та отримав правонаступника «Про національну поліцію».

Взагалі, на МВС покладена величезна задача по реалізації владно-розпорядчих функцій, зокрема видача дозволів, контроль, видання нормативних актів публічного адміністрування та ненормативних актів публічного адміністрування, забезпечення дотримання певних правил, своєчасне і якісне розслідування адміністративних справ, перевірки, або так звані обстеження, організація постійної взаємодії оперативних служб, взяття на облік експериментально відстріляних куль та гільз, створення державної кулегільзотеки, зберігання відстріляних гільз та куль; виготовлення бланків дозволів, тощо.

Слід зазначити про Національну поліцію, яка: здійснює контроль за дотриманням фізичними та юридичними особами спеціальних правил та порядку зберігання і використання зброї, спеціальних засобів індивідуального захисту та активної оборони, боєприпасів, вибухових речовин і матеріалів, інших предметів, матеріалів та речовин, на які поширюється дозвільна система органів внутрішніх справ; здійснює у визначеному законом порядку приймання, зберігання та знищення вилученої, добровільно зданої або знайденої вогнепальної, газової, холодної та іншої зброї, боєприпасів, набоїв, вибухових речовин та пристроїв, наркотичних засобів або психотропних речовин; здійснює перевірку документів у особи, у якої є зброя, обіг якої обмежений або заборонений, або для зберігання, використання чи перевезення якої потрібен дозвіл, якщо встановити такі права іншим чином неможливо; вилучає зброю, спеціальні засоби, боєприпаси, вибухові речовини та матеріали, інші предмети, матеріали і речовини, щодо зберігання і використання яких визначено спеціальні правила чи порядок та на які поширюється дозвільна система органів внутрішніх справ, а також опечатує і закриває об'єкти, де вони зберігаються чи використовуються (у тому числі стрілецькі тири, стрільбища невійськового призначення, мисливські стенди, підприємства і майстерні з виготовлення та ремонту зброї, спеціальних засобів, боєприпасів, магазини, у яких здійснюється їх продаж, піротехнічні майстерні, пункти вивчення матеріальної частини зброї, спеціальних засобів, правил поводження з ними та їх застосування) у випадку виявлення порушення правил поводження з ними та правил їх використання, що загрожують громадській безпеці, до 
The Administrative and Legal Status of the Subjects of Public administration that Provide Legal Support for the Circulation and Use of Weapons in Ukraine, Including Space Weapons by Serhiy Didenko

усунення таких порушень; застосувати вогнепальну зброю, як захід поліцейського примусу, тощо [Про, 2015].

Застосування зброї працівниками правоохоронних органів як крайній вияв адміністративного примусу регламентується законодавством і має свої правові наслідки. Слід зазначити, що для всіх правоохоронних органів загальною нормою по застосуванню зброї, є приписи закону «Про національну поліцію». Цікавим видається той факт, що у відповідності до Закону України «Про Службу Безпеки України» не тільки службові особи мають право на користування зброєю, а й у деяких випадках, зокрема у разі наявності небезпеки для життя і здоров>я особам, взятим ними під захист, можуть видавати відповідно до чинного законодавства зброю [Про Службу, 1992].

Ще одним ваговим актом публічного адміністрування в цій сфері є Постанова Кабінету Міністрів України «Про затвердження Положення про дозвільну систему» від 12 жовтня 1992 р. N 576, в якій зазначено, що контроль за дотриманням посадовими особами міністерств, інших центральних органів державної виконавчої влади, підприємств, установ, організацій, господарських об〉єднань і громадянами встановленого порядку виготовлення, придбання, зберігання, обліку, перевезення і використання предметів, матеріалів і речовин, відкриття та функціонування підприємств, майстерень і лабораторій, на які поширюється дозвільна система, здійснюється безпосередньо МВС, а також МО3, Мінекоресурсів і Держнаглядохоронпраці [Положення, 1992].

Тобто, окрім Міністерства внутрішніх справ України, суб'єктами публічного адміністрування, що здійснюють забезпечення обігу та застосування зброї є ще Міністерство охорони здоров'я України, Міністерство екології та природних ресурсів України та Державна служба України з питань праці. Також, окремі питання щодо обігу та застосування зброї регламентують своїми відомчими актами й інші суб'єкти виконавчої влади діяльність яких, побічно стосується даної сфери публічного життя: Міністерство доходів і зборів України, Державна інспекція України з питань захисту прав споживачів, Міністерство екології та природних ресурсів України, Державне агентство рибного господарства України, Міністерство фінансів України, Міністерство інфраструктури України, Державний комітет України з питань регуляторної політики та підприємництва, Міністерство енергетики та вугільної промисловості України та інші.

Наприклад, Держінспектори органів Мінприроди, які відповідно до чинного законодавства мають право на носіння відомчої зброї під час виконання службових обов'язків, мають право застосовувати їі як крайній захід, в таких випадках: для відбиття групового та збройного нападу на зазначену особу, членів іiї сім>ї або окремих громадян, якщо їхньому життю чи здоров’ю загрожує небезпека для захисту від злочинних посягань на своє житло та майно; для затримання особи, яка вчинила злочин і намагається втекти або вчинити збройний опір; для відбиття збройного чи групового нападу на приміщення державного і громадського підприємства, установи, організації, де працює ця посадова особа; для знешкодження тварин, що загрожують життю чи здоров’ю посадової особи, членів іiї сім>ї або окремим громадянам [Інструкція, 2004].

Тобто, наявність консолідованого нормативно-правового акта в цій сфері, значно покращила б і спростила процес реалізації в ній управлінського механізму. Не беручи до уваги загальної нормативної діяльності держави, найбільший внесок в аналізовану сферу дослідження робить Міністерство внутрішніх справ України разом з його структурними підрозділами. Далі має бути Міністерство юстиції України, а потім інші суб'єкти виконавчої влади діяльність яких, побічно стосується даної сфери публічного життя. 

for the Circulation and Use of Weapons in Ukraine, Including Space Weapons by Serhiy Didenko

\section{Висновки}

Усе вище викладене дає можливість сформулювати наступні висновки, відносно статусу суб’ єктів публічної адміністрації в сфері забезпечення обігу та застосування зброї в Україні, включаючи космічну зброю:

1. Публічна адміністрація в сфері забезпечення обігу та застосування зброї - це сукупність, передбачена законодавством, уповноважених органів та посадових осіб, наділених адміністративно-управлінськими функціями щодо належного забезпечення обігу та застосування зброї, діяльність яких базується на певних обов'язкових адміністративних принципах з метою задоволення публічних інтересів в межах сфери їх правового впливу;

2. Основне завдання публічної адміністрації полягає у цілеспрямованому впливі певних владних суб’єктів на конкретну сферу суспільного життя, що потребує на основі інтересу держави і суспільства врегулювання шляхом реалізації їх законодавчо прописаної компетенції;

3. Поняття «правовий статус» охоплює своїм змістом місце в системі державних органів конкретного суб'єкта, який безпосередньо здійснює регулюючий вплив в конкретній сфері суспільного життя на основі своєї компетенції, а адміністративно-правовий статус, це більш конкретне поняття, яке охоплює своїм змістом певні складові елементи за допомогою який з'являється можливість дослідити місце певного суб'єкта в усій системі регулюючого впливу з боку держави на певні суспільні відносини;

4. Статус, основні завдання, організація та принципи діяльності, права та обов'язки, заходи соціального і правового захисту, відповідність в сфері обігу та застосування зброї, включаючи космічну зброю, повинні бути передбачені у спеціально створеному законі, якого, в цій сфері наразі немає.

\section{Література}

Інструкція про порядок виготовлення, придбання, зберігання, обліку, перевезення та використання вогнепальної, пневматичної і холодної зброї, пристроїв вітчизняного виробництва для відстрілу патронів, споряджених гумовими чи аналогічними за своїми властивостями метальними снарядами несмертельної дії, та зазначених патронів, а також боєприпасів до зброї та вибухових матеріалів: Наказ МВС України від 21 серп. 1998 р. № 622. Офічійний вісник Украӥни. 42, 1998. Ст. 1574.

Інструкція про порядок придбання, зберігання, обліку, перевезення, використання та застосування вогнепальної зброї, бойових припасів до зброї, пристроїв вітчизняного виробництва для відстрілу патронів, споряджених гумовими чи аналогічними за своїми властивостями метальними снарядами несмертельної дії, та зазначених патронів, а також спеціальних засобів державними інспекторами з охорони навколишнього природного середовища органів, що входять до сфери управління Міністерства охорони навколишнього природного середовища України : Наказ Міністерства охорони навколишнього природного середовища України від 12 жовт. 2004 р. №386. Офіиійний вісн. Украӥни. 2004. № 44. Ст. 2937.

Кравцова, Тетяна, і Анастасія Солонар. Поняття та принципи діяльності публічної адміністрації. Форум права. 4, 2010: 522-525. http://www.nbuv.gov.ua/e-journals/ FP/2010- 4/10ktmdpa.pdf 
The Administrative and Legal Status of the Subjects of Public administration that Provide Legal Support for the Circulation and Use of Weapons in Ukraine, Including Space Weapons by Serhiy Didenko

Положення про дозвільну систему: Постанова Кабінету Міністрів України від 12.10.1992 № 576. http://zakon3.rada.gov.ua/laws/show/576-92-П

Про Національну поліцію: Закон України від 02.07.2015. Відомості Верховної Ради України. 2015 р. № 40-41. Ст. 1970.

Про Службу безпеки України: Закон України від 25.03.1992. Відомості Верховної Ради України. 1992 р. № 27.

Ринажевський, Богдан. Компетенція та повноваження військової служби правопорядку (служби правопорядку) у Збройних Силах України. Право і Безпека. 1, 2010: 1521.

Словник іншомовних слів. За ред. О. С. Мельничука. Київ: Наук. думка, 1974.

Шиленко, Микола. Адміністративно-правовий статус суб'єктів публічної адміністрації, що здійснюють охорону природних ресурсів. Інформація і право. 2, 2014: 97-101.

Ding, Zhou, An Zhang, Huan Chang, and Zhenglin Chen. Research on Operational Effectiveness of Space-Based Weapon and Sensitivity Analysis. $20168^{\text {th }}$ International Conference on Intelligent Human-Machine Systems and Cybernetics (IHMSC), 2016. https://orcid. org/10.1109/IHMSC.2016.42

Zubko, Artem. Administrative and Legal Status of Public Administration, which Carries out Administrative and Legal Regulation in Ukrainian Space Defense. Advanced Space Law, Volume 1, 2018: 98-107. https://orcid.org/10.29202/asl/2018/1/12

\section{[ㅁ] References}

Instruktsiia pro poriadok vyhotovlennia, prydbannia, zberihannia, obliku, perevezennia ta vykorystannia vohnepalnoi, pnevmatychnoi i kholodnoi zbroi, prystroiv vitchyznianoho vyrobnytstva dlia vidstrilu patroniv, sporiadzhenykh humovymy chy analohichnymy za svoimy vlastyvostiamy metalnymy snariadamy nesmertelnoi dii, ta zaznachenykh patroniv, a takozh boieprypasiv do zbroi ta vybukhovykh materialiv: Nakaz MVS Ukrainy vid 21 serp. 1998 r. № 622. Ofitsiinyi visnyk Ukrainy. 42, 1998. St. 1574.

Instruktsiia pro poriadok prydbannia, zberihannia, obliku, perevezennia, vykorystannia ta zastosuvannia vohnepalnoi zbroi, boiovykh prypasiv do zbroi, prystroiv vitchyznianoho vyrobnytstva dlia vidstrilu patroniv, sporiadzhenykh humovymy chy analohichnymy za svoimy vlastyvostiamy metalnymy snariadamy nesmertelnoi dii, ta zaznachenykh patroniv, a takozh spetsialnykh zasobiv derzhavnymy inspektoramy z okhorony navkolyshnoho pryrodnoho seredovyshcha orhaniv, shcho vkhodiat do sfery upravlinnia Ministerstva okhorony navkolyshnoho pryrodnoho seredovyshcha Ukrainy : Nakaz Ministerstva okhorony navkolyshnoho pryrodnoho seredovyshcha Ukrainy vid 12 zhovt. 2004 r. №386. Ofitsiinyi visn. Ukrainy. 2004. № 44. St. 2937.

Kravtsova, Tetiana, i Anastasiia Solonar. Poniattia ta pryntsypy diialnosti publichnoi administratsii. Forum prava. 4, 2010: 522-525. http://www.nbuv.gov.ua/e-journals/ FP/2010- 4/10ktmdpa.pdf

Polozhennia pro dozvilnu systemu: Postanova Kabinetu Ministriv Ukrainy vid 12.10.1992 № 576. http://zakon3.rada.gov.ua/laws/show/576-92-p

Pro Natsionalnu politsiiu: Zakon Ukrainy vid 02.07.2015. Vidomosti Verkhovnoi Rady Ukrainy. 2015 r. № 40-41. St. 1970.

Pro Sluzhbu bezpeky Ukrainy: Zakon Ukrainy vid 25.03.1992. Vidomosti Verkhovnoi Rady Ukrainy. 1992 r. № 27. 

for the Circulation and Use of Weapons in Ukraine, Including Space Weapons by Serhiy Didenko

Rynazhevskyi, Bohdan. Kompetentsiia ta povnovazhennia viiskovoi sluzhby pravoporiadku (sluzhby pravoporiadku) u Zbroinykh Sylakh Ukrainy. Pravo i Bezpeka. 1, 2010: 1521.

Slovnyk inshomovnykh sliv. Za red. O. S. Melnychuka. Kyiv: Nauk. dumka, 1974.

Shylenko, Mykola. Administratyvno-pravovyi status subiektiv publichnoi administratsii, shcho zdiisniuiut okhoronu pryrodnykh resursiv. Informatsiia i pravo. 2, 2014: 97-101.

Ding, Zhou, An Zhang, Huan Chang, and Zhenglin Chen. Research on Operational Effectiveness of Space-Based Weapon and Sensitivity Analysis. $20168^{\text {th }}$ International Conference on Intelligent Human-Machine Systems and Cybernetics (IHMSC), 2016. https://orcid. org/10.1109/IHMSC.2016.42

Zubko, Artem. Administrative and Legal Status of Public Administration, which Carries out Administrative and Legal Regulation in Ukrainian Space Defense. Advanced Space Law, Volume 1, 2018: 98-107. https://orcid.org/10.29202/asl/2018/1/12 